\title{
Means of Automating the Hierarchical Design of Complex Microelectronic Circuits with Uncertainty of Design Rules
}

\author{
S.E. Mironov, A.Yu. Vasiliyev, N.M. Safyannikov \\ Saint-Petersburg Electrotechnical University “LETI”, St. Petersburg, semironovspb@yandex.ru
}

\begin{abstract}
The paper contains the study results for processtolerant high-density layout design of hierarchical regular and irregular VLSI macroblocks. Process tolerance is ensured by the one-dimensional compaction algorithm based on the virtual grid, and high density by the original method of iterative stage-by-stage matching of cells and their pins location. The authors propose the structural model of complex irregular circuits' layout, which simplifies their cells matching. The description of the developed system and the technique of hierarchical layout design of complex microelectronic circuits are also presented.
\end{abstract}

Keywords - design rules; process-tolerant design; layout compaction; high density design; cell size matching; matching of cells pins location.

\section{INTRODUCTION}

Complication of microelectronic circuits and systems has led to creation of automation aids for the VLSI layout design, which could quickly adapt the layout to the technological requirements of the manufacturer. The said aids have been named systems of process-tolerant design based on the layout compaction, because adjustment to the required design rules is implemented by moving layout elements located in the abstract sparse space as close to each other as possible. Actuality of the process-tolerant design is connected with the constant improvement of design rules.

There are different approaches to the building of systems of hierarchical process-tolerant layout design of complex microelectronic circuits [1]. Some aspects of compaction connected with the matching of dimensions and pins location of cells were considered in the works of the authors [2], [3]. The current paper describes software and the technique of regular and irregular VLSI macroblocks design that has been created by the authors for the design in conditions of design rules uncertainty.

The process-tolerance of the layout projects of VLSI macroblocks is achieved with the aid of the cells compaction system "TopDesign" [4], which minimizes the distance between elements according to the design rules and additional restrictions imposed by the developer for relative positions of different parts of the layout.

Scientific and technical novelty is connected with the original method [2], [3], [5] of iterative step-by-step matching of cells sizes and location of their pins, which was developed for the "Matching of Cells" system of macroblocks layout design.

\section{STRUCTURAL MODEL OF IRREGULAR COMPLEX MICROELECTRONIC CIRCUITS FOR THE AUTOMATION OF HIERARCHICAL DESIGN}

One of the key problems in layout adjustment to the required design rules is matching of dimensions and pins coordinates of a large number of cells. The process of matching of pairs of pins is carried out step-by-step taking into account the current changes of pins location in neighboring cells. In so doing, the situations can emerge, requiring returning to the earlier matched pins of the neighboring cells to correct their positions. The process is being done iteratively, and it significantly effects layout generation time.

Reduction of the matching time was achieved due to the development of the method of priority order search for cells matching. For example, two options of pins matching for $N$ cells are presented in Fig. 1, initially compacted without considering pins location. In the worst case (Fig. 1, a) after the matching of every pair of pins it is necessary to re-match all the earlier matched pairs. In the best case (Fig. 1, b) re-matching is not needed at all. The number of matching stages for one layer of cells' pins lies in the range from $(N \times(N-1) / 2)$ to $(N-1)$.

The second problem of hierarchical design automation is connected with the determination of coordinates of pins being matched in irregular hierarchic circuits.

Layouts of complex microelectronic circuits with regular matrix-type structures are made as matrices of cells with the same column widths and the same row heights.

Therefore dimensions and location of cells' pins are leveled off with respect to the general point of reference, the same for all the cells. The left edge of the cells column and the lower edge of the row act as the points of reference.

For irregular microelectronic circuits a structural model has been developed, which provides easy cells matching in macroblocks. Within the framework of the model, when pins' and bounds' positions of cells not united into rows or columns are being determined, the positions should be counted down from the bounds of the latest processed cells of the circuit: upper bounds of lower cells and right bounds of left cells (Fig. 2).

For example, in Fig. 2 coordinates of «A» pins of the 3$\mathrm{d}$ and 4-th cells on axis $Y$ are determined by the expressions:

$$
Y_{A}=Y_{1}+Y_{3 A}, \quad Y_{A}=Y_{2}+Y_{4 A},
$$



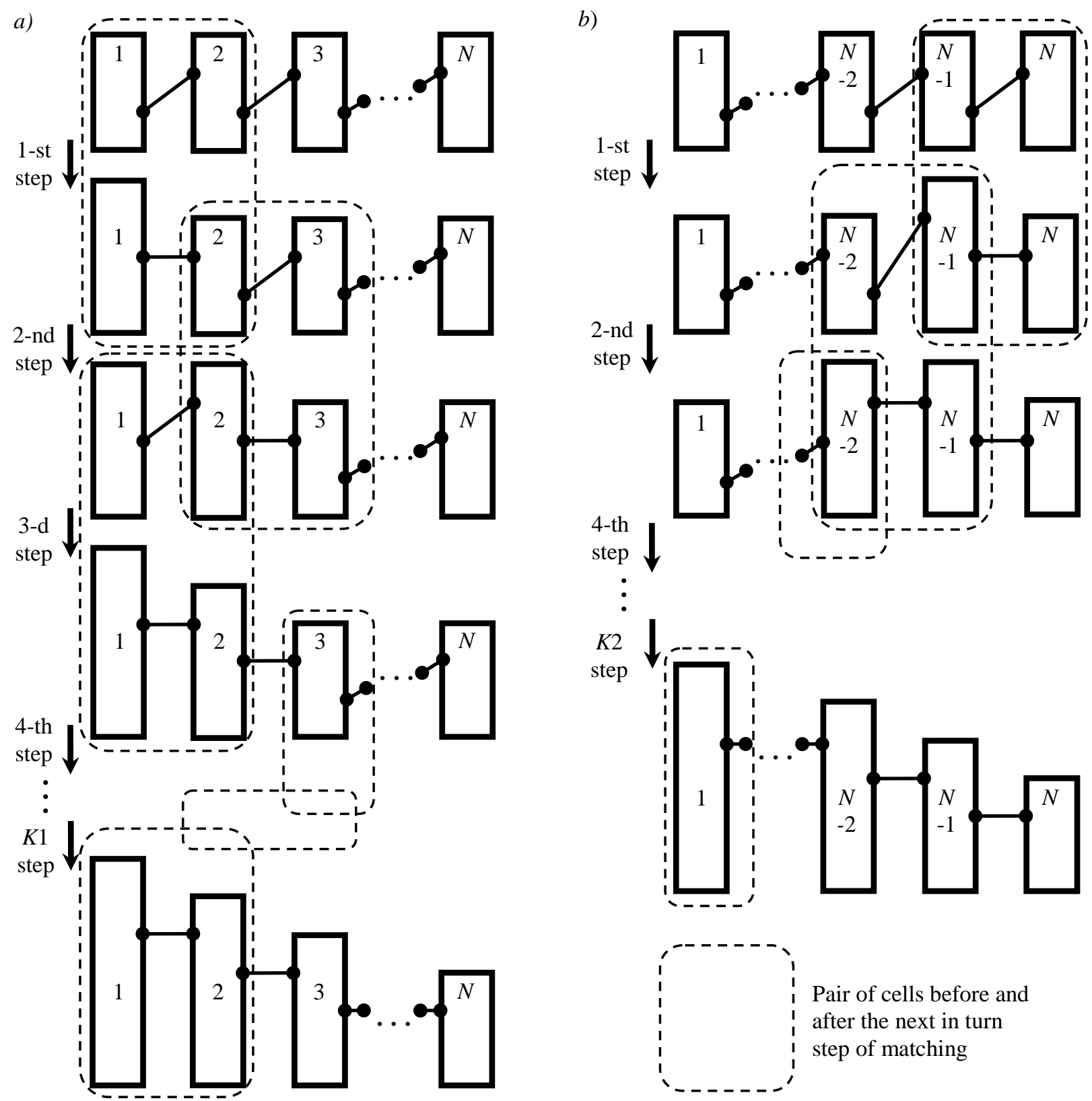

Fig. 1. Examples of pin location matching for $N$ cells in the worst (a) and best (b) case

where $Y_{1}$ and $Y_{2}$ areheights of the cells 1 and 2 respectively, and $Y_{3 A}$ and $Y_{4 A}$ - coordinates on axis $Y$ of «A» pins of the cells 3 and 4 .

Hence, when compaction algorithms are used for the complex microelectronic circuits design, the concept of a fence, i.e. a broken line, repeating the bounds of the latest processed cells, is applicable to cells as well as to elements of their layout.

So, principles of matching sizes and pins location of cells of regular complex microelectronic circuits were extended to irregular microelectronic circuits that are more generalized case of VLSI macroblocks.
It allowed development of graphical editor of structural layout plans, which has become one of constituents of layout macroblocks design system "Matching of Cells".

The main window of the graphic editor with the windows containing graphical descriptions of microelectronic circuits of different types is shown in Fig. 3. 


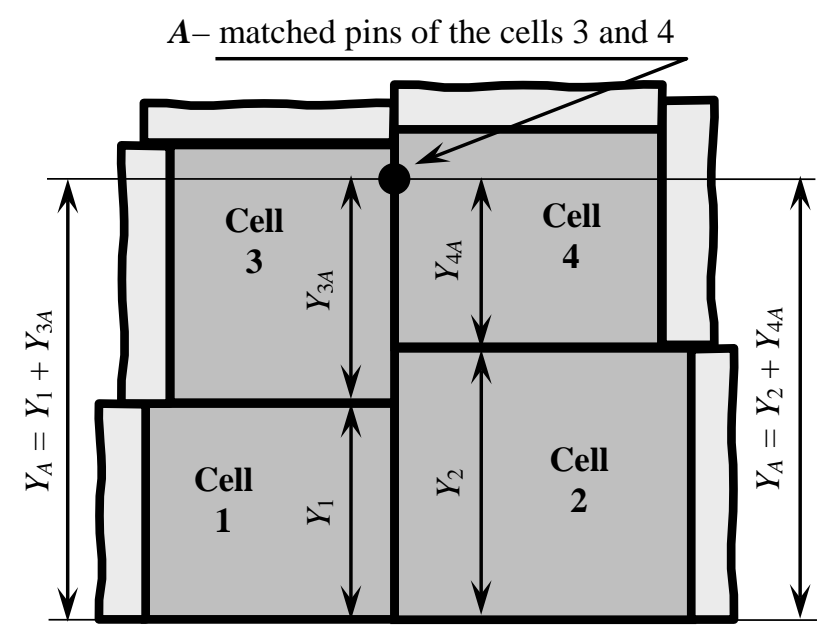

Fig. 2. Determination of cell pins location during their matching according to the proposed structural model of irregular complex microelectronic circuits

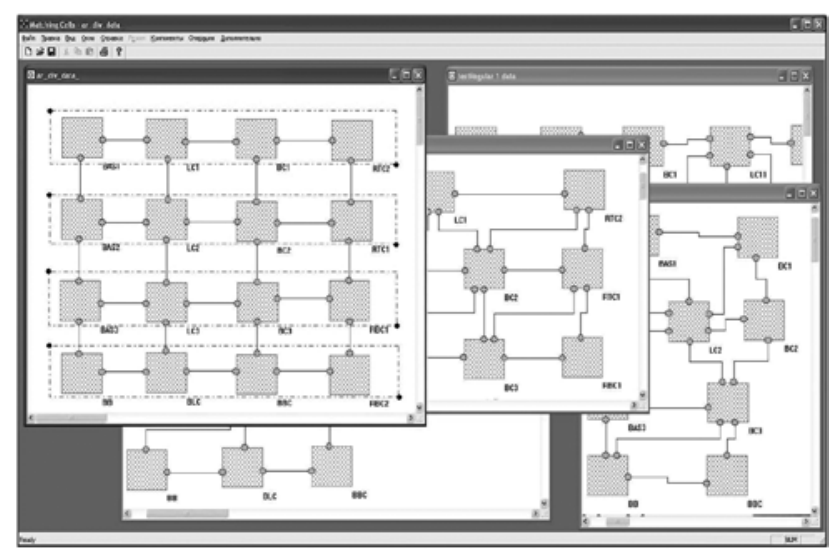

Fig. 3. Thewindowofthe editor of "MatchingofCells" system

III. THE STRUCTURE OF “MATCHING OFCELLS” SYSTEM OF HIERARCHICAL LAYOUT DESIGN OF COMPLEX MICROELECTRONIC CIRCUITS IN CONDITIONS OF DESIGN RULES UNCERTAINTY

The generalized structure of "MatchingofCells" system of hierarchical process-tolerant layout design of macroblocks is shown in Fig. 4.

The following data enter the input of the system of hierarchical layout design:

- files of cells' layout sketches,

- specifications of cells,

- specification of a macroblock.

The files of cells' layout sketches are created in the system of symbolic-level design “TopDesign”[4]. Using the system of virtual coordinates, only relative positions of layout elements are described there (higher or lower, more to the left or to the right). Exact real coordinates of layout elements are determined in the process of cells' layout compaction in specific design rules.

The files of cells' specifications contain descriptions of cells' bounds and pins. They could be both formed in the text editor and generated by software on base of the data from the files of cells' layout sketches.

The files of macroblock specification are either designed in the graphical editor of structural layout plans of "MatchingofCells" system (Fig. 3) or are formed according to the developed syntax of specifications in the text editor.

The files of hierarchical specification of macroblocks are structured text description of the layout being designed, and consist of a name of a structural element, type of its spatial orientation (horizontal $(g)$ or vertical $(v)$ ) and the list of names of included elements of the lower level, arranged from the left to the right or from the top down, and the number of such elements.

The following hierarchical structural description of the matrix divider macroblock, the structural layout plan of which is shown in Fig. 5, is presented here as an example.

SH2 g: B, 1 ;LC, 1 ; BASC, 2 ; RTC2, 1 ; EOL

SH1 g: B, 1 ;LC, 1 ; BASC, 2 ; RTC1, 1 ; EOL

SL1 g: B, 1 ;LC, 1 ; BASC, 2 ; RBC1, 1 ; EOL

SL2 g: BB, 1 ;BLC, 1 ; BC, 2 ; RBC2, 1 ; EOL

Dividerv: SH2, 1 ;SH1 , 4 ; SL1, 4 ; SL2 , 1 ; EOL

In the structured specification above:

Divider - the name of matrix divider macroblock;

$S H 2, S H 1$, SL1, SL2 - the names of macroblock's rows;

$B, B B, L C, B L C, B A S C, B C, R T C 2, R T C 1, R B C 1, R B C 2$ - the names of cells in the macroblock's rows;

1, 2 - matrixing factors of cells in rows' specifications;

1, 4 - matrixing factors of rows in the divider matrix specification.

“MatchingofCells” system of CMOS VLSI hierarchical macroblocks layout design consists of three modules:

- module of structural layout design of macroblocks,

- module of macroblock cells matching,

- module of macroblocks layout building.

The data are loaded into the "MatchingofCells" system from the source data files or from the macroblock project file. The description of the VLSI macroblock structural layout plan can be loaded from the corresponding files as well as designed by means of the graphical editor. The module of macroblocks' structural layout design includes:

- graphical structural layout editor of VLSI macroblocks providing checkup of macroblocks description correctness,

- generator of macroblocks' cells matrices, 


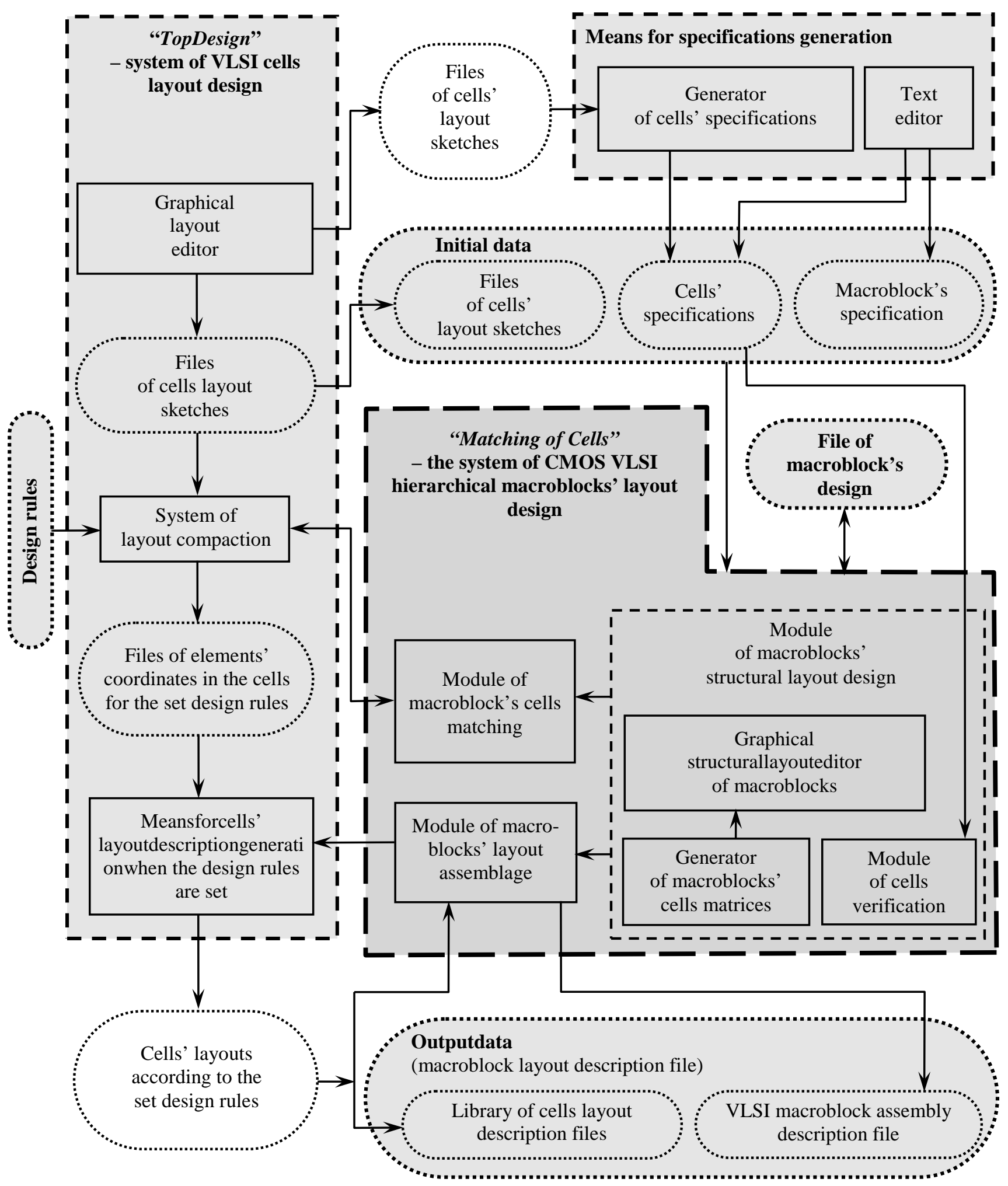

Fig. 4. Generalized structure of the "MatchingofCells"system of hierarchical layout design of complex microelectronic circuits in conditions of uncertainty of design rules

- module of cells’ verification.

After the loading or generation of macroblock's data they are transferred to the module of macroblock cells' matching. This part of "MatchingofCells" system carries out: 
- calculation of limitations on pins location and cells' boundaries according to the set design rules,

- cells' layout compaction (by the means of "TopDesign" compaction system) taking into account not only design rules but the calculated limitations on size and pins coordinates,

- calculation of cells' size.

The result of "MatchingofCells" system work is the hierarchically structured file of VLSI macroblock layout description, generated by the macroblocks' layout assembly module on base of the macroblock structure data, which are received from the module of VLSI macroblock's structural layout design. The file includes:

- library of cells' layout description files;

- description of rows and columns assembling of VLSI macroblock from cells;

- description of VLSI macroblock assembling from rows and columns.

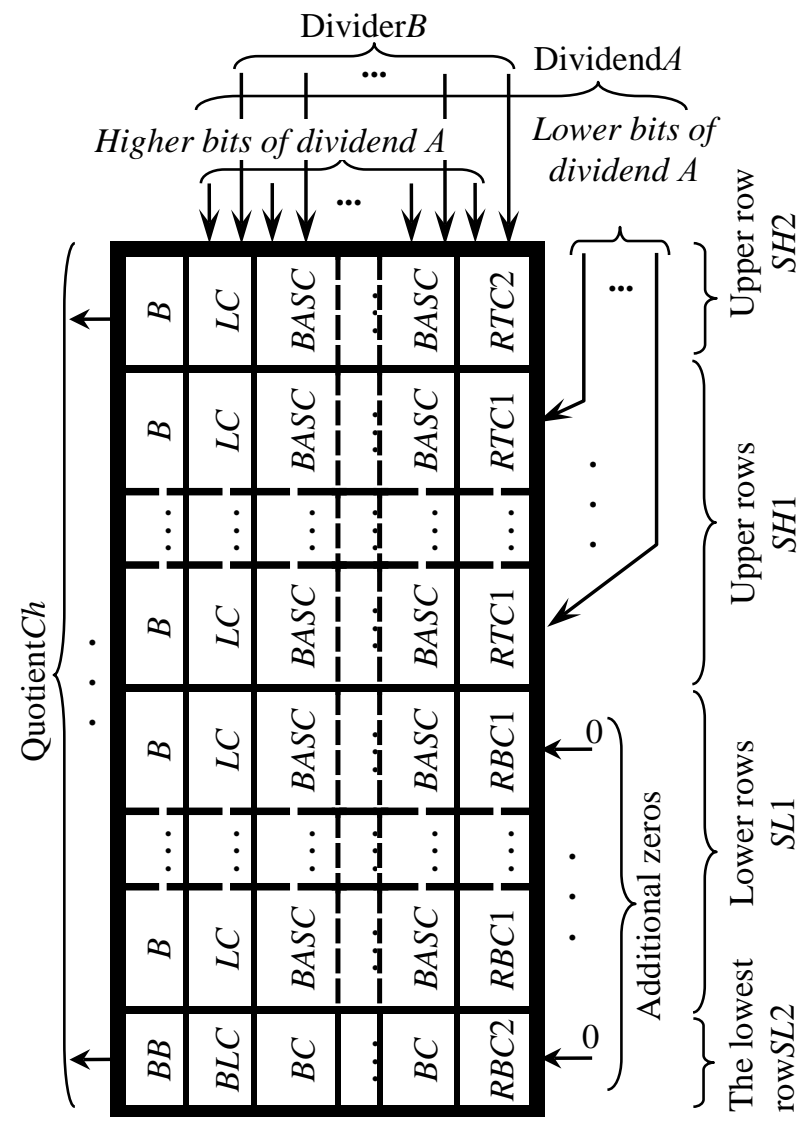

Fig. 5. Structural layout plan of a matrix divider

Irregular VLSI macroblocks can be assembled not from rows and columns, but immediately from cells.

The system puts out the following data for the user to control the process of macroblocks' layout generation:

- on the entered initial structure,

- on the progress in different operations.
Fig.6 illustrates “Matching of Cells” system description and the given below technique of macroblock layout hierarchical design, presenting examples of VLSI hierarchical macroblocks' structural plans and the layouts received with their aid.

IV. PROCEDURE OF HIERARCHICAL LAYOUT DESIGN OF VLSI MACROBLOCKS WITH THE AID OF GRAPHICAL EDITOR OF “MATCHINGOFCELLS” SYSTEM

VLSI macroblock layout description in compliance with the required design rules is formed by way of software generation following the given below stages of macroblock layout hierarchical design.

1. Design of structural layout plan of VLSI macroblock.

2. Design of cells' circuits, cells' layout sketches in “TopDesign"system and VLSI macroblock's cells specifications.

3. Development of the VLSI macroblock's text specification - hierarchical description of the VLSI macroblock's structural layout plan. In case of a macroblock having a matrix structure its specification can be loaded into the graphical editor. But for complex macroblocks with the irregular organization the description of their structure should be assembled from cells and connecting buses in graphical structural-layout macroblocks' editor of “MatchingofCells” system.

4. Generation of the macroblock's cells layout description in compliance with the set design rules with the aid of "MatchingofCells" system. It is implemented with automatic matching of cells' size and location of cells' pins according to structural layout plan of the macroblock.

5. Generation of the macroblock layout hierarchical description file by "MatchingofCells" system.

This methodology fundamentally differs from the one described in [5]. The difference consists in the fact the technique presented above allows:

- describe and create irregular structures;

- both load text description and form descriptions in the dialog box.

Moreover, the reduced procedure of layout generation by software can be applied. It is specified for the cases when macroblock structural layout plan already exists, the library of the matched cells is available, and only parameters of macro-block being designed (data length) are to be changed. Then it is enough to load the available project and to set new values of matrixing factors of the cells in structural modules (rows/columns) and the modules in the macroblock, and carry out the assembling operation.

\section{CONCLUSION}

The presented above technique of hierarchical layout design with the aid of "MatchingofCells" system has been successfully applied within the framework of state assignment of the Ministry of Education and Science of the Russian Federation No. 8.2080.2017/4.6 during the works 
continuing the studies of the authors on the design of

complexity. microelectronic circuits both of small [6] and large [7]
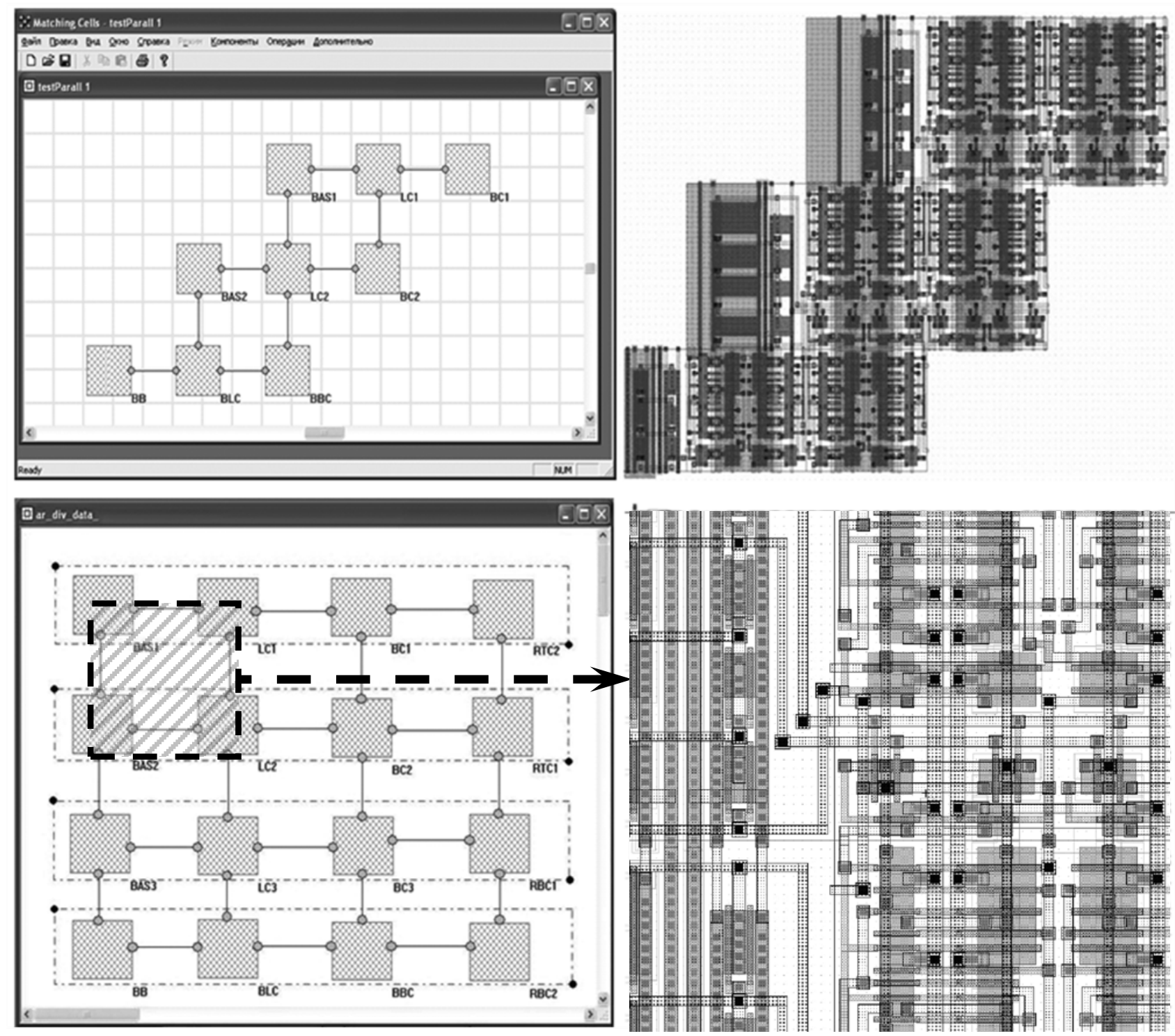

Fig. 6. Examples of structural plans of VLSI hierarchical macroblocks and layouts built on their base

The main results are the following ones:

- original method of iterative step-by-step matching of cells' sizes and location of their pins, which ensures high density of VLSI hierarchical blocks layout;

- structural model of complex microelectronic circuits providing simple matching of cells in irregular macroblocks;

- "Matching ofCells" system of process-tolerant hierarchical design of VLSI macroblocks layout;

- technique of macroblocks' layout hierarchical design in "MatchingofCells" system.

\section{ACKNOWLEDGEMENTS}

The authors express their gratitude to assistant professor of Saint-Petersburg state electrotechnical university "LETI" I.S. Zuev for his constant attention and practical assistance in the surveyed research area.

\section{SUPPORT}

The results have been achieved within the framework of state assignment of the Ministry of Education and Science of the Russian Federation No. 8.2080.2017/4.6.

\section{REFERENCES}

[1] Bamji C., Varadarajan, R.Leaf Cell and Hierarchical Compaction Techniques, New York - Springer Science \& Business Media, LLC, Dec 6, 2012 - Technology \& Engineering - 161 p., DOI 10.1007/978-1-4615-6139-2.

[2] Mironov S.E., Vasil'ev A.Yu. Avtomatizatsiya tekhnologicheski invariantnogo ierarkhicheskogo proektirovaniya topologii regulyarnykh makroblokov SBIS (Automation of process tolerant hierarchical design of the layout of regular VLSI macroblocks) // Komp'yuternye 
nauki i informatsionnye tekhnologii: Materialy mezhdunar. nauch. konf., g. Saratov, 1-4 iyulya 2012. - Saratov: Nauka, 2012. - S. 204-208 (in Russian).

[3] Mironov S.E., Vasil'ev A.Yu. Upravlenie protsessom soglasovaniya slozhnykh topologicheskikh ob"ektov mikroelektronnykh sistem $\mathrm{v}$ usloviyakh neopredelennosti proektnykh norm (Managing the process of matching complex layout objects of microelectronic systems under conditions of uncertainty in design rules) // Materialy II mezhdunarodnoy nauchnoy konferentsii po problemam upravleniya v tekhnicheskikh sistemakh (STS'2017). Sankt-Peterburg, SPbGETU «LETI», 2017 g., 25 - 27 oktyabrya, s. 198-201 (in Russian).

[4] Zuev I.S., Maximov A. High-Density Layout Designing of CMOS VLSI Parameterized Fragments // Proceedings of IEEE East-West Design \& Test Symposium (EWDTS'10). - St.Petersburg, 2010. - P. 131-134.

[5] Mironov S.E., Vasil'ev A.Yu. Iteratsionnoe szhatie s ogranicheniyami pri ierarkhicheskom tekhnologicheski invariantnom proektirovanii topologii makrofragmentov SBIS (Iterative compaction with constraints in the hierarchical process tolerant design of the VLSI macrofragments layout) // Izvestiya SPbGETU «LETI». Ser. «Informatika, upravlenie i komp'yuternye tekhnologii». - 2010. - Vyp. 3. - S. 10-15 (in Russian).

[6] Safyannikov N.M., Baranov A.A. Skhemo-topologicheskoe proektirovanie yacheek SBIS (Circuit-and-layout design of VLSI cells) // VII-ya Vserossijskaya nauchnotekhnicheskaya konferenciya «Problemy razrabotki perspektivnyh mikro- i nanoehlektronnyh sistem - 2016»: Sbornik trudov / pod obshch. red. akademika RAN A.L. Stempkovskogo. Zelenograd, 3 - 7 oktyabrya 2016 g. - M. IPPM RAN, 2016. - CH III. - S. 220 - 225 (in Russian).

[7] Safyannikov N.M., $\quad$ Frolkin A.K. Strukturnye preobrazovaniya makroblokov SBIS putyom peregruppirovki ih funkcional'no odnorodnyh zon (Structural transformations of VLSI macroblocks by regrouping their functionally homogeneous zones ) // VII-ya Vserossijskaya nauchno-tekhnicheskaya konferenciya «Problemy razrabotki perspektivnyh mikro- i nanoehlektronnyh sistem - 2016»: Sb. trudov / pod obshch. red. akademika RAN A.L. Stempkovskogo. Zelenograd, 3 7 oktyabrya 2016 g. - M: IPPM RAN, 2016. - CH III. - S. 226 - 231 (in Russian). 